\title{
Paleolimnological evidence for increased sexual reproduction in chydorids (Chydoridae, Cladocera) under environmental stress
}

\author{
Liisa NEVALAINEN ${ }^{1) *}$, Tomi P. LUOTO ${ }^{1,2)}$, Suzanne LEVINE $^{3)}$ and Marina MANCA ${ }^{4)}$ \\ ${ }^{1)}$ Institute for Limnology, Austrian Academy of Sciences, Mondseestraße 9, 5310 Mondsee, Austria \\ ${ }^{2)}$ Department of Geosciences and Geography, University of Helsinki, P.O. Box 64, 00014 University of Helsinki, Finland \\ ${ }^{3)}$ Rubenstein School of Environment and Natural Resources, University of Vermont, Burlington, VT 05405, USA \\ ${ }^{4)}$ CNR Institute for Ecosystem Study, Largo Tonolli 52, 28922 Verbania, Italy \\ *email corresponding author: liisa.nevalainen@oeaw.ac.at
}

\begin{abstract}
To investigate the extent to which anthropogenic perturbations such as eutrophication and trace metal pollution (i.e., environmental stress sensu Odum 1985) influence the reproductive modes of cladoceran populations, we analyzed the abundance of subfossils of the chydorids Alonella nana (Baird, 1850) and Alona affinis (Leydig, 1860) in sediment cores from three Finnish lakes. Reconstruction of lakes' pollutant history and the biological response of chydorids indicate that in two of the lakes the proportion of individuals reproducing sexually increased with environmental stressors. More specifically, A. nana responded to eutrophication in Lake Hampträsk with greater production of ephippia, while A. affinis responded to aluminum pollution or acidification in Lake Pieni Majaslampi. In contrast, the reference lake, Lake Iso Lehmälampi, showed no radical changes in sexual reproduction over the twomillennium long sediment record. We conclude that chydorids may use sexual reproduction as a strategy for overcoming unexpected environmental stresses.
\end{abstract}

Key words: aquatic environments, Crustacea, diapause, subfossils, eutrophication, pollution

\section{INTRODUCTION}

"Environmental stress" is an expression widely used by ecologists to indicate externally applied forces detrimental to ecosystems (Odum et al. 1979; Odum 1985). Environmental stress disrupts ecosystem homeostasis and sometimes changes biological structure (e.g., species composition) and function (e.g., metabolism). According to Odum $(1969,1985)$, external disturbances of low predictability to which organisms have not pre-adapted are most likely to have negative consequences for energetics, nutrient cycling, community structure or other system-level properties. Elliot \& Quintino (2007) describe environmental stress as a perturbation that reduces the ability of biological systems to organize, function, and survive, with possible disruption at the level of cell, individual, population, community, or ecosystem.

The influence of environmental stress on the biological functioning of cladocerans (Crustacea) is relatively well established for the widely used genus Daphnia, family Daphniidae. For example, Hanazato \& Dodson (1995) and Boersma et al. (1999) have shown that the life-history characteristics (e.g., growth rate and body size) of Daphnia are affected by exposure to predator kairomones, low oxygen and pesticides. Also, sexual reproduction and subsequent diapause in Daphnia species have been related to environmental stressors, such as shortening day-length, decline in food availability and increased fish predation (Stross \& Hill 1965; Hobæk \& Larsson 1990; Pijanowska \& Stolpe 1996).
For other species less common of family Chydoridae, similar relationships have been implied to be present (Nevalainen \& Sarmaja-Korjonen 2008) but are yet to be adequately established.

In the current study, we use paleolimnological data to evaluate long-term changes in the relative importance of sexual versus asexual reproduction in populations of Alonella nana (Baird) and Alona affinis (Leydig). Sexual reproduction was reconstructed by means of subfossil ephippia of the two species. From previous studies we knew that one of the study lakes had undergone eutrophication (Lake Hampträsk), while atmospheric pollution, involving aluminum and resulting in severe acidification, had occurred in another (Lake Pieni Majaslampi). A third lake (Iso Lehmälampi), for which previous work (Nevalainen et al. 2008) indicated a lack of exposure to serious environmental stressors over temporal resolution of the examined sediment core, was included as a reference for the reproductive changes. Our goal was to investigate whether changes in sexual reproduction occur in populations under stress. We hypothesized that sexual reproduction, resulting in diapausal resting eggs and renewed genotypes, could be used as a mechanism for maintaining population homeostasis; i.e. the ability to perform fundamental functions and to sustain vital properties under environmental stress. In addition to the high viability of the resting eggs after dormancy under environmentally unfavorable periods, sexual reproduction increases genetic diversity via meiosis and fertilization (Frey 

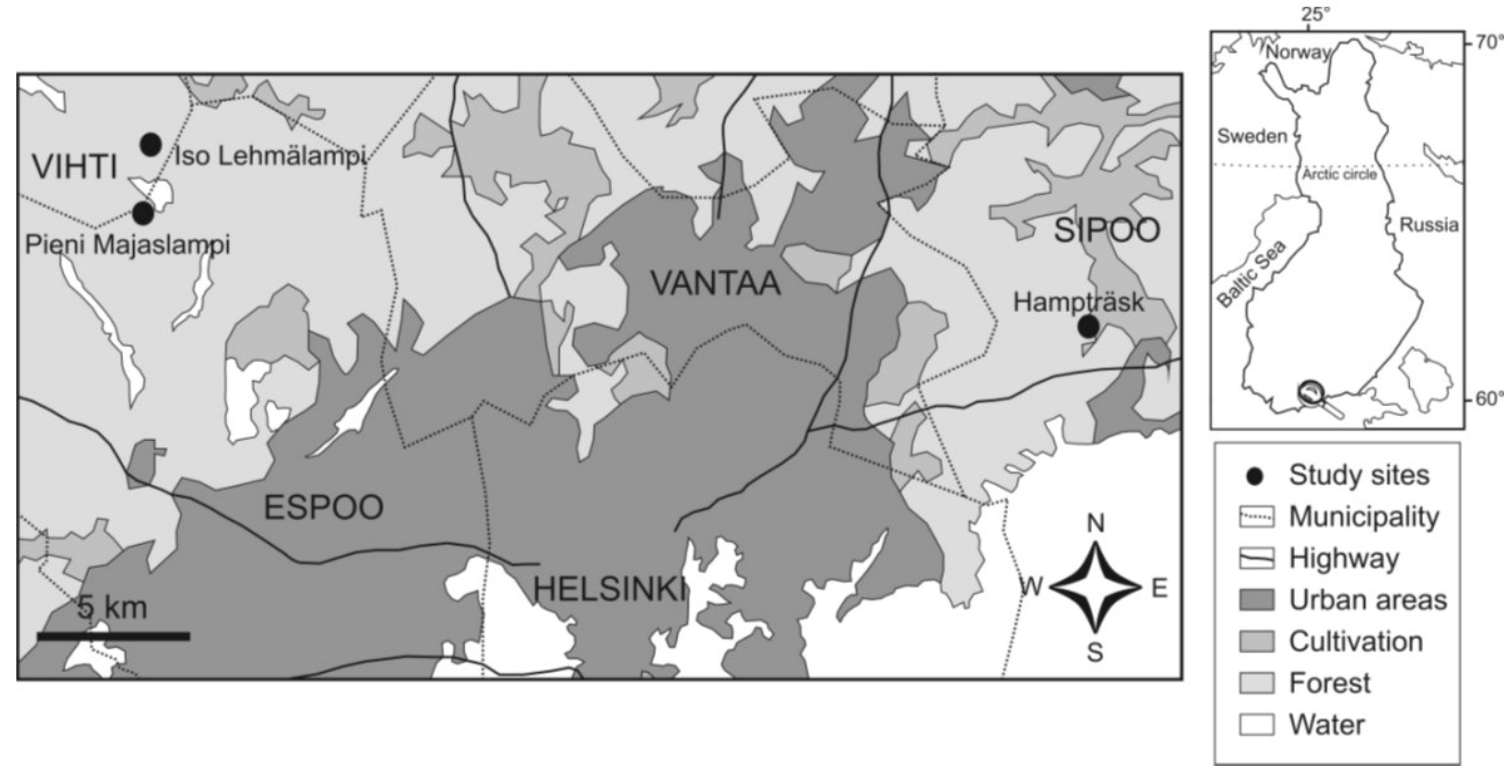

Fig. 1. Location of the study lakes in southern Finland.

1982), increasing also the likelihood that the next generations include stress-tolerant members.

\section{METHODS}

Study lakes Hampträsk $\left(60^{\circ} 17^{\prime} \mathrm{N}, 25^{\circ} 15^{\prime} \mathrm{E}\right)$, Iso Lehmälampi $\left(60^{\circ} 20^{\prime} \mathrm{N}, 24^{\circ} 36^{\prime} \mathrm{E}\right)$, and Pieni Majaslampi $\left(60^{\circ} 19^{\prime} \mathrm{N}, 24^{\circ} 35^{\prime} \mathrm{E}\right)$ are located in southern Finland very close to one another (Fig. 1). The basic limnological variables from the study lakes are presented in table 1 . Hampträsk is a eutrophic lowland lake, lying in a clay basin. The lake is shallow (max. depth $\sim 2.5 \mathrm{~m}$ ) and small (surface area $\sim 3.8 \mathrm{ha}$ ). The lake has suffered from nutrient enrichment during past centuries due to increased agricultural land-use in the catchment (Sarmaja-Korjonen 1992; Luoto et al. 2008). Lakes Iso Lehmälampi (max. depth $8.1 \mathrm{~m}$, surface area $\sim 5.1 \mathrm{ha}$ ) and Pieni Majaslampi ( $\sim 6.6 \mathrm{~m}, \sim 1.1 \mathrm{ha})$ are oligotrophic and acidic upland lakes lying on granitic bedrock. Due to the limnological and catchment characters, the two lakes can be considered to be sensitive to atmospheric loading (Virkanen et al. 1997) and they acidified badly during 1980s (Verta et al. 1990; Nyberg et al. 2010). Lake selection was based on previous studies (Verta et al. 1990; Virkanen et al. 1997; Luoto et al. 2008; Luoto \& Salonen 2010), which indicated a history of severe anthropogenic disturbances (eutrophication and atmospheric pollutants) in them.

Short sediment cores were collected through the ice of lakes Hampträsk $(46 \mathrm{~cm})$ and Iso Lehmälampi $(24 \mathrm{~cm})$ with a Limnos gravity corer (Kansanen et al. 1991) during late winter of 2005 . The cores were subsampled in the field at $1 \mathrm{~cm}$ intervals and stored in a cold room (at $4{ }^{\circ} \mathrm{C}$ and in the dark) for later microfossil analyses. The topmost $14 \mathrm{~cm}$ of the sediment core from Lake Pieni Majaslampi was collected with a freeze corer (cf.
Rymer \& Neale 1981) through the ice during late winter 2006 and subsampled in the laboratory at $0.5 \mathrm{~cm}$ intervals. Several samples from Lakes Hampträsk (at depths 16, 22, 29, 32, 35, $44 \mathrm{~cm}$ ) and Iso Lehmälampi (at depths 13, 18, $24 \mathrm{~cm}$ ) were radiocarbon dated (AMS technique) using terrestrial macrofossils and bulk sediment samples at the Poznán Radiocarbon Laboratory in Poland (Tab. 2). The age-depth models used in age estimations of the present study were originally presented by Luoto et al. (2008) for Lake Hampträsk and by Nevalainen et al. (2008) for Lake Iso Lehmälampi. Instead, the sediment core (12 samples) from Lake Pieni Majaslampi was dated at the Laboratory of Quaternary Geochronology, Institute of Geological Sciences, Poland, using ${ }^{210} \mathrm{~Pb}$ methodology and the CRS agedepth model (Tab. 2, Nevalainen 2008a).

In the laboratory, the sediment samples were prepared for subfossil Cladocera analysis using the procedures described in Szeroczyńska and Sarmaja-Korjonen (2007). For ephippium analysis (Sarmaja-Korjonen 2003, 2004), subfossil chydorid remains were counted until a minimum of 200 chydorid carapaces + ephippia were enumerated in each sample. In the present study, only data from carapaces and ephippia of Alonella nana and Alona affinis were used. From the relative proportions of carapaces and ephippia, we obtained rough estimates of the relative proportion of asexual versus sexual reproduction over time. We used smoothing spline technique (smooth 2.0) to illustrate general temporal trends in sexual reproduction using the program PAST (Hammer et al. 2001). Cladocera statigraphies of the three lakes are provided by Luoto et al. (2008), Nevalainen et al. (2008) and Nevalainen (2008a). Chydorid ephippia stratigraphies from lakes Hampträsk and Pieni Majaslampi are presented in Luoto et al. (2008) and Nevalainen (2008a), respectively. Data on the 
Tab. 1. Basic limnological properties of the study lakes. The measurements were performed in situ from the littoral zones in three seasons during ecological monitoring of modern chydorid communities in 2005.

\begin{tabular}{cllcc}
\hline & Season & \multicolumn{3}{c}{ Lakes } \\
\cline { 3 - 5 } & & Hampträsk & Pieni Majaslampi Iso Lehmälampi \\
\hline \multirow{3}{*}{$\mathrm{pH}$} & Spring & 7.0 & 5.1 & 5.3 \\
& Summer & 6.6 & 4.9 & 5.1 \\
& Winter & 5.4 & 4.8 & 5.8 \\
Conductivity & Spring & 41 & 11 & 14 \\
$\left(\mu \mathrm{S} \mathrm{cm}^{-1}\right)$ & Summer & 49 & 16 & 17 \\
& Winter & 44 & 20 & 20 \\
Oxygen & Spring & 9.0 & 9.9 & 8.4 \\
$\left(\mathrm{mg} \mathrm{L}^{-1}\right)$ & Summer & 9.2 & 9.7 & 8.9 \\
& Winter & 5.4 & 11.0 & 18.1 \\
Color Pt & Spring & 75 & 5 & 20 \\
$\left(\mathrm{mg} \mathrm{L}^{-1}\right)$ & Summer & 75 & 25 & 30 \\
& Winter & 75 & 15 & 40 \\
$\mathrm{TP}$ & Spring & 30 & $<10$ & $<10$ \\
$\left(\mathrm{mg} \mathrm{L}^{-1}\right)$ & Summer & 28 & $<10$ & 25 \\
& Winter & 13 & $<10$ & 10 \\
$\mathrm{TN}$ & Spring & 981 & 227 & 343 \\
$\left(\mathrm{mg} \mathrm{L}^{-1}\right)$ & Summer & 1123 & 191 & 382 \\
& Winter & 808 & 217 & 457 \\
\hline
\end{tabular}

Tab. 2. Results of ${ }^{14} \mathrm{C}$ - and ${ }^{210} \mathrm{~Pb}$-dating (CRS model) for cores of the study lakes. For Lake Hampträsk, the chronology was estimated based on the terrestrial macrofossils, as the bulk sediment dates were considered unreliable (see Luoto et al. 2008).

\begin{tabular}{c|cccc}
\hline & Depth $(\mathrm{cm})$ & Dated material & Age $\pm(\mathrm{AD})$ & Remarks \\
\hline \multirow{2}{*}{$\begin{array}{c}\text { Iso Lehmälampi } \\
\left({ }^{14} \mathrm{C}\right)\end{array}$} & 13 & Piece of tree & $1095 \pm 46$ & \\
& 24 & Bulk & $512 \pm 53$ & \\
& 16 & Bulk & $89 \pm 28$ & Too young \\
Hampträsk & 22 & Bulk & & Too small \\
$\left({ }^{14} \mathrm{C}\right)$ & 22 & Seed & & \\
& 29 & Catkin scale & $1489 \pm 115$ & Small $(0.12 \mathrm{mg} \mathrm{C})$ \\
& 32 & Bulk & $1369 \pm 42$ & \\
& 35 & Seed & $1550 \pm 61$ & Small $(0.15 \mathrm{mg}$ C) \\
& 44 & Seed & $1362 \pm 40$ & \\
& 1 & & $2005 \pm 0.5$ & \\
& 2 & & $2004 \pm 0.3$ & \\
& 3 & & $2002 \pm 1$ & \\
Pieni Majaslampi & 4 & & $1994 \pm 2$ & \\
$\left({ }^{20}\right.$ Pb) & 5 & & $1987 \pm 3$ & \\
& 7 & & $1978 \pm 2$ & \\
& 8 & & $1969 \pm 5$ & \\
& 9 & & $1966 \pm 2$ & \\
& 10 & & $1951 \pm 2$ & \\
& 11 & & $1941 \pm 5$ & \\
& 12 & & $1931 \pm 25$ & \\
\hline
\end{tabular}

abundance of $A$. nana (ephippia and carapaces) in lakes Hampträsk and Iso Lehmälampi are discussed in Nevalainen et al. (2011).

Spearman's rank correlation coefficient $\left(r_{S}\right)$ was used to test statistical significance of relationships between sexual reproduction in Alonella nana and chironomidinferred total phosphorus in Lake Hampträsk and sexual reproduction of Alona affinis and aluminum accumulation in Lake Pieni Majaslampi. A moving average (MA) technique with 2-intervals, conventionally used for smoothing data in time series analysis (Shumway \& Stoffer 2006), was applied to the data on sexual reproduction and environmental variables; MA values were then additionally used for correlation analysis.

The chironomid-based TP inference model applied to the Hampträsk core was based on data from 41 shallow lakes in Finland (reduced model) having a coefficient of determination $\left(r_{\text {jack }}^{2}\right)$ of 0.92 and a root mean square error of prediction (RMSEP) of $7.3 \mu \mathrm{g} \mathrm{L}^{-1}$ (Luoto 2011). Data on sedimentary Al accumulation in Lake 

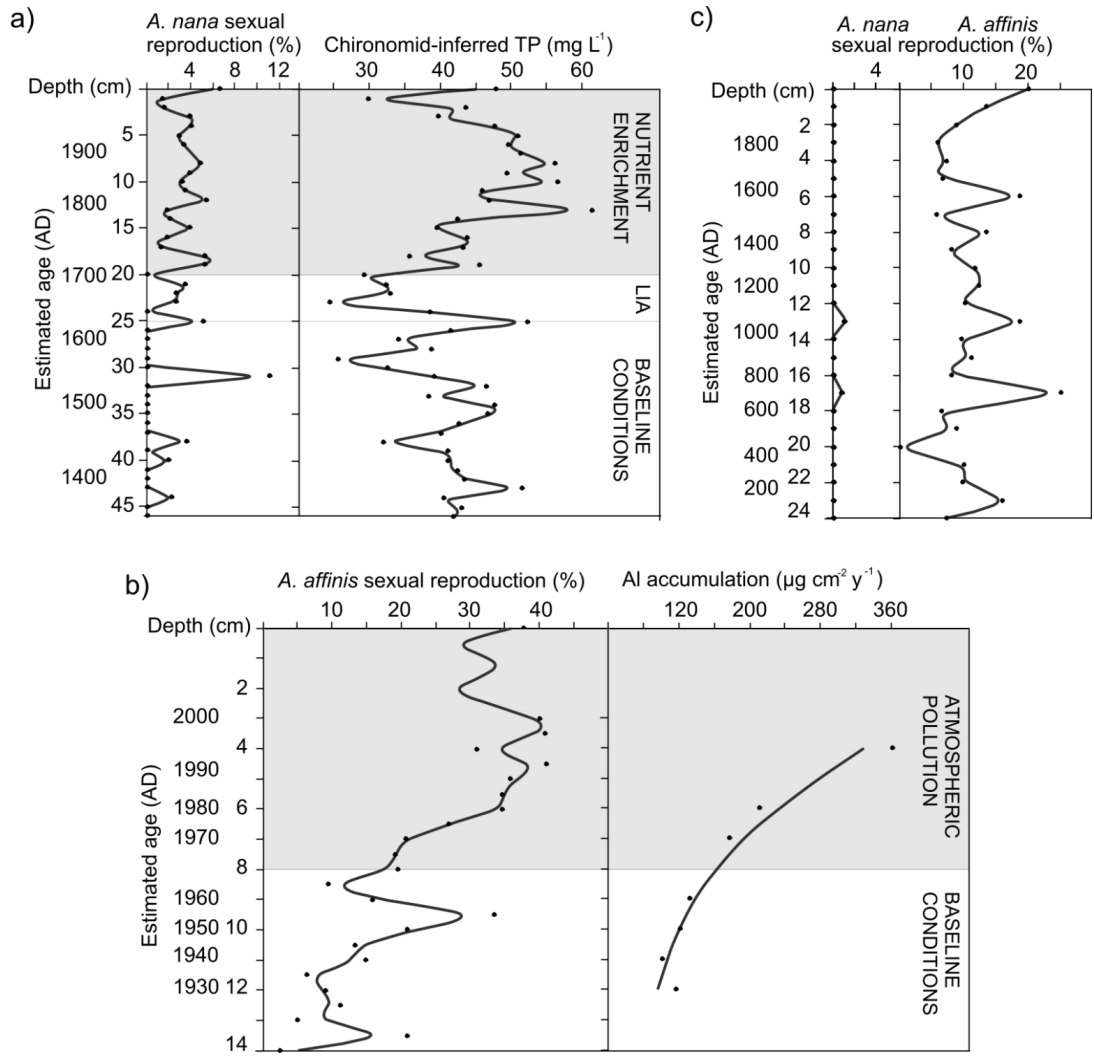

Fig. 2. Long-term trends (smoothing done with smoothing spline method) in incidence of sexual reproduction in Alonella nana and Alona affinis as reconstructed from ephippia in sediment cores from a) Lake Hampträsk (past 700 y), b) Lake Pieni Majaslampi (past $\sim 100 \mathrm{y}$ ), and c) Lake Iso Lehmälampi (past $\sim 2000$ y). Periods of environmental stress (eutrophication in Lake Hampträsk, atmospheric pollution in Lake Pieni Majaslampi) are indicated as gray bands, while trends in the pollutant (chironomid-inferred total phosphorus and aluminum accumulation rate) are plotted alongside the ephippia data. The culmination period (Luoto et al. 2008) of the Little Ice Age (LIA) is marked for the Hampträsk core.

Pieni Majaslampi in 1990, 1980, 1970, 1960, 1950, 1940, and $1930 \mathrm{AD}$ were taken from Virkanen et al. (1997), determined with atomic absorption spectrophotometry.

\section{RESULTS}

The ${ }^{14} \mathrm{C}$-dating of the Iso Lehmälampi core was based on one terrestrial macrofossil and two bulk sediment samples, which were in chronological order and had small estimation errors (Tab. 2), providing a valid chronology. According to the dating results, the $24 \mathrm{~cm}$ sediment section represents past $\sim 2000$ years. On the contrary, the bulk dates from Lake Hampträsk showed inconsistent dates when compared to the dates from terrestrial macrofossils (Tab. 2). Because Lake Hampträsk has been affected for centuries by agricultural land-use, the bulk sediments may have contained older carbon from allochtonous source and therefore the chronology presented here follows the age estimations based on macrofossil dating results (see Luoto et al. 2008 for further discussion). Based on the terrestrial macrofossil dates, the $46 \mathrm{~cm}$ sediment profile represents the time period from $\sim 1300 \mathrm{AD}$ until present. The chronology of the Pieni Majaslampi core, based on ${ }^{210} \mathrm{~Pb}$-dating, may also contain some problems, since ${ }^{210} \mathrm{~Pb}$ specific activity was uniform in the uppermost $9 \mathrm{~cm}$ of the core (not shown here). This may be due to sediment mixing or alternatively be a result of post-depositional remobilization and transport of lead along the sediment column without any mixing. However, since there were clear faunal changes within the $9 \mathrm{~cm}$ section (Nevalainen 2008a, Fig. 2) it is likely that uninterrupted sedimentation has prevailed in the lake allowing reliable age estimation of the core (Tab. 2). According to the CRS model, the $14 \mathrm{~cm}$ section represents roughly the past $\sim 100$ years.

Long-term ( $\sim 700$ years) changes in the proportion of asexual/sexual reproduction of Alonella nana and Alona affinis populations from the three study lakes are illustrated in figure 2. Sexual reproduction by A. nana in Lake Hampträsk was very low and sporadic prior to lake eutrophication (Fig. 2a), although there was a temporary increase (up to $\sim 10 \%$ ) at $c a 1550 \mathrm{AD}(30 \mathrm{~cm}$ depth in the core). From $20 \mathrm{~cm}$ depth $(\sim 1700$ AD) to the topmost sediment section, the incidence of sexual reproduction by $A$. nana increased, so that surface ephippia made $\sim 6 \%$. The proportion of sexual reproduction was generally $\sim 5 \%$ and the average for the core was $2.2 \%$. The chironomid-inferred TP concen- 
trations in the core varied between 24 (at $23 \mathrm{~cm}$ ) and 61 $\mu \mathrm{g} \mathrm{L}^{-1}$ (at $13 \mathrm{~cm}$ ) (Fig. 2a). A general decline in TP was observed prior to $1700 \mathrm{AD}$ (during the LIA), after which an increasing trend was recorded between $\sim 1800$ and $1900 \mathrm{AD}$.

In Lake Pieni Majaslampi Alona affinis reproduced sexually with much higher proportions (average 23.9\%) during the past $\sim 100$ years as $A$. nana in Hampträsk. The proportion of sexual reproduction in $A$. affinis increased abruptly up to about $30 \%$ at a sediment depth of $10 \mathrm{~cm}$, which corresponded to a date of about 1950 AD. There was a sharp decrease from $c a 1950$ to 1960 $\mathrm{AD}$, before rising more steadfastly after $\sim 1960 \mathrm{AD}$. The highest values $(\sim 40 \%)$ were recorded in the late 1980s and early 1990s (Fig. 2b). Corresponding values for Al accumulation rate were around $100 \mu \mathrm{g} \mathrm{cm}^{-2} \mathrm{y}^{-1}$ in the 1930 and 1940 s, rising rapidly after 1950 s to exceed $350 \mu \mathrm{g} \mathrm{cm}^{-2} \mathrm{y}^{-1}$ in the 1990s (Virkanen et al. 1997, Fig. 2b).

Both $A$. nana and $A$. affinis were present in sediments from Lake Iso Lehmälampi but $A$. nana ephippia were found in low numbers and only at two sediment depths, 13 and $17 \mathrm{~cm}$, suggesting that this population reproduced almost exclusively asexually. For A. affinis, we calculated an average incidence of sexual reproduction of $10.8 \%$. No temporal pattern of ephippia production was discernable over the roughly 2000 years assessed (Fig. 2c).

The Spearman's rank correlation coefficient for $A$. nana and chironomid-inferred TP was moderate $\left(r_{S}=\right.$ $0.27, p=0.07, \mathrm{n}=47)$, and non-significant at $p \leq 0.05$. For $A$. affinis and $\mathrm{Al}$ accumulation rate however, it was high and statistically significant $\left(r_{S}=0.82, p=0.034, \mathrm{n}\right.$ $=7$ ). When 2-interval moving averages for species and environmental data were used, all correlations increased in strength and were significant at $p \leq 0.05$ (Tab. 3 ).

Tab. 3. Spearman's correlation coefficients $\left(r_{S}\right)$ and significance levels $(p)$ for relationships between sexual reproduction in Alonella nana and chironomid-inferred total phosphorus in Lake Hampträsk and sexual reproduction in Alona affinis and aluminum accumulation rate in Lake Pieni Majaslampi. Correlations based on 2-interval moving average values for sexual reproduction and environmental variables are marked in boldface.

\begin{tabular}{l|cc}
\hline & $r_{S}$ & $p$ \\
\hline \multirow{2}{*}{ Alonella nana (Hampträsk) } & 0.27 & 0.07 \\
& $\mathbf{0 . 3 0}$ & $\mathbf{0 . 0 4 1}$ \\
Alona affinis (Pieni Majaslampi) & 0.82 & 0.034 \\
& $\mathbf{0 . 9 3}$ & $\mathbf{0 . 0 0 7}$ \\
\hline
\end{tabular}

\section{DISCUSSION AND CONCLUSIONS}

The role of sexual reproduction in cyclical parthenogens is well established (Maynard Smith 1968; Frey 1982; Rispe \& Pierre 1998; Pękalski 2000). Its occurrence still attracts the attention of scientists, probably because it can be regarded as a paradox (Hurst \& Peck 1996; Doncaster et al. 2000); males contribute to popu- lation growth only through females. Sexual reproduction is, in fact, a mechanism through which populations buffer the risk and damage of unexpected external environmental perturbations. It allows a temporary escape from unfavorable conditions through diapause and an increase of the population fitness as the greater genetic variability of the following generation permits selection of better adapted organisms (Lynch \& Gabriel 1983; Hurst \& Peck 1996). Thus, it is a reaction to stress, as defined by Odum (1985). Spatial variations in the proportion of cladoceran sexual reproduction are obvious in the literature (e.g., Cáceres \& Tessier 2004; Nevalainen 2008b), indicating local adaptations among populations. The present study shows that even adjacent cladoceran populations may exhibit strong variations in their reproductive strategies when local environmental conditions are different (cf. Cáceres \& Tessier 2004; Nevalainen 2008b).

Our paleolimnological data provide evidence for temporal changes in the reproductive strategies of chydorid species, and suggest that they are coincident with long-term environmental change. In Lake Iso Lehmälampi, our reference system, co-occurring $A$. nana and $A$. affinis populations maintained relatively consistent distributions of sexually and asexually reproducing individuals over two millennia (Fig. 2c). This is in contrast with increasing incidence of sexual reproduction in the other two lakes that have been exposed to serious environmental stress (Fig. 2a, 2b). Sarmaja-Korjonen (2003) anticipated this response of chydorids to environmental stressors after noting a sudden increase in the proportion of ephippia of $A$. affinis and A. nana in two sediment cores from lakes in southern Finland. She hypothesized that increased nutrient input and/or altered food-web structure were forcing factors in the change. The increase in sexual reproduction that we observed in the two polluted study lakes was also coincident with the onset of anthropogenic stresses. At $\sim 1700 \mathrm{AD}$ an increasing land-use brought more nutrients into Lake Hampträsk (Luoto et al. 2008; Luoto \& Salonen 2010) and, as a consequence, $A$. nana increased ephippia production, instead in Lake Pieni Majaslampi A. affinis increased sexual reproduction at $\sim 1960 \mathrm{AD}$ as atmospheric pollution became more severe (Virkanen et al. 1997) and resulted in acidification and dramatic food-web changes. In both cases, we found statistically significant correlations between proportions of sexual reproduction and the magnitude of the stressor (Tab. 3). Furthermore, both perturbations (eutrophication and atmospheric pollution) are well-documented stressors for aquatic ecosystems (Schindler et al. 1985; Cattaneo et al. 1998; Manca et al. 2007; Jeppesen et al. 2009), and are expected to influence directly or via indirect forcing mechanisms on population homeostasis of chydorids.

In our reference lake (Iso Lehmälampi), no distinct trends were found in the reproduction patterns of $A$. 
nana and $A$. affinis (Fig. 2c). Lake Iso Lehmälampi, although it is known to have suffered from heavy acidification due to atmospheric loading during 1980s, showed no clear indication of anthropogenic stress-induced environmental forcing on chydorids (Nevalainen et al. 2008). This is most likely due to the rough temporal resolution of the sediment core; the $24 \mathrm{~cm}$ sediment core, subsampled at $1 \mathrm{~cm}$ resolution, appeared to represents past 2000 years (Tab. 2) and therefore the most recent anthropogenic impacts are not clearly reflected in the stratigraphy. However, it is worth mentioning that sexual reproduction in A. affinis increased markedly in the most recent sediment samples $(0-2 \mathrm{~cm}, \sim 1900 \mathrm{AD}$ onward) and this can be indicative of environmental stress related to atmospheric loading (Fig. 2c).

Evidence for a serious increase in the trophic state of Lake Hampträsk was provided by Luoto et al. (2008), who reconstructed the lake's trophic history in a multiproxy paleolimnological investigation. They attributed the change to an increase in agricultural land use in the lake catchment beginning around 1800 AD. Furthermore, in-lake oxygen concentration, inferred from sedimentary chironomid-stratigraphy, declined concurrent with eutrophication (Luoto \& Salonen 2010). Rising trophic state also was evident in the current study from the chironomid-inferred TP reconstruction from the sediment core (Fig. 2a). We interpret the increase in sexual reproduction of $A$. nana population as a response to eutrophication stress, which, most likely, acted both directly (by disturbing population homeostasis e.g. via decreased oxygen concentration in bottom waters) and indirectly (changes in food-web). Our interpretation is supported by the fact that the proportion of sexual reproduction of $A$. nana is correlated with the inferred TP in-lake concentration (Tab. 3).

Virkanen et al. (1997) found that Lake Pieni Majaslampi received heavy atmospheric loading of several biologically harmful metals (e.g., $\mathrm{Al}, \mathrm{Cd}, \mathrm{Pb}$ ), and that the influx increased markedly between the 1960s and 1980s. Trends in aluminum accumulation in the sediment core of the lake clearly confirm this atmospheric pollution (Fig. 2b, Virkanen et al. 1997). Virkanen et al. (1997) mainly attributed the increase in sedimentary aluminum accumulation to dry precipitation of particles from the atmosphere. During the 1980s, however, Lake Pieni Majaslampi was affected severely by acid precipitation, which decreased $\mathrm{pH} \quad(\sim 4.5)$, increased labile-aluminum concentrations in the water, and severely damaged aquatic communities (Nyberg et al. 2010). For example, the natural perch (Perca fluviatilis) population was extirpated and the food-web changed as invertebrates were established as toppredators (Nyberg et al. 2010). Aluminum is a toxic metal having direct effects on aquatic biota and also cascading indirect effects (Havens 1990, Nilssen \& Sandøy 1990, Sparling \& Lowe 1996, Soucek et al. 2001). The increase in sexual reproduction of A. affinis, coincident with the elevated $\mathrm{Al}$ accumulation and onset of acidification during 1970-1980s (Fig. 2), may thus have been a homeostatic response to either direct (physiological) stress under changed chemical conditions or to stresses induced through indirect effects, such as altered food-resources and increased benthic invertebrate predation. Most likely, it involved both pathways, and could have been aggravated by the toxicity of metals co-occurring with aluminum.

Cladocera, primarily Daphniidae, have been used in aquatic toxicology as test organisms because of their short life cycle, easy culturing, and sensitivity to chemicals (Münzinger \& Mocelli 1991; Muyssen et al. 2002; Lam \& Wang 2008; Ponti et al. 2010). In the case of chydorids, however, toxicological studies have been rare (Koivisto et al. 1992; Bossuyt \& Janssen 2005). To our knowledge, the only publication reporting effects of toxins on chydorid sexual reproduction was published a long time ago by Kiser et al. (1963) who found that the annual induction of sexual reproduction in chydorids occurred earlier than previously observed at similar latitudes after toxic pesticide (rotenone) was discharged into the lake. Kiser et al. (1963) implied for the first time that sexual reproduction might be regarded as a response of chydorids to environmental stress caused by pollution. We further suggest that this response may be a general reaction to the disturbance of population homeostasis, because similar effects were observed in the present study following two very different types of anthropogenic impacts, eutrophication and metal pollution (Fig. 2). It appears that changes in the water chemistry of the study lakes along with cascading ecological consequences (deteriorated oxygen, altered predation regime) forced chydorid populations to undergo intensified sexual reproduction to escape unfavorable conditions and ensure the survival of future populations through genetic adaptation to the new environmental ranges. Sexual reproduction seems to have a vigorous role in maintaining population homeostasis in cladocerans, whether providing diapause and preserving the vitality of future populations or improving genetic heterogeneity under unexpected environmental stresses. In addition to using subfossil cladocera assemblages as indicators of multiple anthropogenic environmental stressors (DeSellas et al. 2011), we emphasize the importance and usability of subfossil ephippia in paleolimnological investigations for providing information about periods of environmental disturbance.

\section{ACKNOWLEDGMENTS}

Financial support was provided by the Academy of Finland for L.N. (EPHIPPIUM project) and by the Kone Foundation for T.P.L. (LOSER project, LOng-term climate impactS on lakE tRophic status). We thank two anonymous reviewers for their valuable remarks on the manuscript. 


\section{REFERENCES}

Boersma, M., L. De Meester \& P. Spaak. 1999. Environmental stress and local adaptation in Daphnia magna. Limnol. Oceanogr., 44: 393-402.

Bossuyt, B.T.A. \& C.R. Janssen. 2005. Copper toxicity to different field-collected cladoceran species: intra- and interspecies sensitivity. Environ. Poll., 136: 145-154.

Cáceres, C.E. \& A.J. Tessier. 2004. Incidence of diapause varies among populations of Daphnia pulicaria. Oecologia, 141: 425-431.

Cattaneo, A., A. Asioli, P. Comoli \& M. Manca. 1998. Organisms' response in a chronically polluted lake supports hypothesized link between stress and size. Limnol. Oceanogr., 43: 1938-1943.

DeSellas, A.M., A.M. Paterson, J.N. Sweetman \& J.P. Smol. 2011. Assessing the effects of multiple environmental stressors on zooplankton assemblages in Boreal Shield lakes since pre-industrial times. J. Limnol., 70: 41-56.

Doncaster, C.P., G.E. Pound \& S.J. Cox. 2000. The ecological cost of sex. Nature, 404: 281-285.

Elliot, M. \& V. Quintino. 2007. The estuarine quality paradox, environmental homeostasis and the difficulty of detecting anthropogenic stress in naturally stressed areas. Mar. Poll. Bull., 54: 640-645.

Frey, D.G. 1982. Contrasting strategies of gamogenesis in northern and southern populations of Cladocera. Ecology, 63: 223-241.

Hammer, Ø., D.A.T. Harper \& P. D. Ryan. 2001. PAST: Paleontological Statistics Software Package for Education and Data Analysis. Palaeontologia Electronica 4(1): 9pp. http://palaeo-electronica.org/2001_1/past/issue1_01.htm.

Hanazato, T. \& S.I. Dodson. 1995. Synergistics effects of low oxygen concentration, predator kairomone, and a pesticide on the cladoceran Daphnia pulex. Limnol. Oceanogr., 40: 700-709.

Havens, K.E. 1990. Aluminum binding to ion exchange sites in acid-sensitive versus acid-tolerant cladocerans. Environ. Pollut., 64: 133-141.

Hobæk, A. \& P. Larsson. 1990. Sex determination in Daphnia magna. Ecology, 71: 2255-2268.

Hurst, L.D. \& J.R. Peck. 1996. Recent advances in understanding of the evolution and maintenance of sex. Trends Ecol. Evol., 11: 46-52.

Jeppesen, E., B. Kronvang, M. Meerhoff, M. Søndergaard, K.M. Hansen, H.E. Andersen. T.L. Lauridsen, L. Liboriussen, M. Beklioglu, A. Özen \& J.E. Olesen. 2009. Climate change effects on runoff, cathment phosphorus loading and lake ecological state, and potential adaptations. J. Environ. Qual., 38: 1930-1941.

Kiser, R.V., J.R. Donaldson \& P.R. Olson. 1963. The effect of rotenone on zooplankton populations in freshwater lakes. Trans. Amer. Fish. Soc., 92: 17-24.

Kansanen, P.H., T. Jaakkola, S. Kulmala, \& R. Suutarinen. 1991. Sedimentation and distribution of gamma-emmitting radionuclides in bottom sediments of southern Lake Päijänne, Finland, after the Chernobyl accident. Hydrobiologia, 222: 121-140.

Koivisto, S., M. Ketola \& M. Walls. 1992. Comparison of five cladoceran species in short- and lon-term copper exposure. Hydrobiologia, 248: 125-136.

Lam, I.K.S. \& W.-X. Wang. 2008. Trace element deficiency in freshwater cladoceran Daphnia magna. Aquat. Biol., 1: 217-224.

Luoto, T.P. 2011. The relationship between water quality and chironomid distribution in Finland - A new assemblagebased tool for assessments of long-term nutrient dynamics. Ecol. Indic., 11: 255-262.

Luoto, T.P. \& V.P. Salonen. 2010. Fossil midge larvae (Diptera: Chironomidae) as quantitative indicators of latewinter hypolimnetic oxygen in southern Finland - A cali- bration model, case studies and potentialities. Bor. Env. Res., 15: 1-18.

Luoto, T.P., L. Nevalainen \& K. Sarmaja-Korjonen. 2008. Multi-proxy evidence for the "Little Ice Age" from Lake Hampträsk, Southern Finland. J. Paleolimnol., 40: 10971113.

Lynch, M. \& W. Gabriel. 1983. Phenotypic evolution and parthenogenesis. Am. Nat., 122: 745-764.

Manca, M., B. Torretta, P. Comoli, S.L. Amsinck \& E. Jeppesen. 2007. Major changes in trophic dynamics in large, deep sub-alpine Lake Maggiore from 1940a to 2002: a high resolution comparative palaeo-neolimnological study. Freshwat. Biol., 52: 2256-2269.

Maynard Smith, J. 1968. Evolution in sexual and asexual populations. Am. Nat., 102: 469-473.

Münzinger, A. \& F. Monicelli. 1991. A comparison of sensitivity of three Daphnia magna populations under heavy metal stress. Ecotox. Environ. Safety, 22: 24-31.

Muyssen, B.T.A., C.R. Janssen \& B.T.A. Bossyut. 2002. Tolerance and acclimation to zinc of field-collected Daphnia magna populations. Aquat. Tox., 56: 69-79.

Nevalainen, L. 2008a. Sexual reproduction in chydorid cladocerans (Anomopoda, Chydoridae) in southern Finland implications for paleolimnology. Academic dissertation. University of Helsinki, Department of Geology, Helsinki: 54 pp.

Nevalainen, L. 2008b. Parthenogenesis and gamogenesis in seasonal succession of chydorids (Crustacea, Chydoridae) in three low-productive lakes as observed with activity traps. Pol. J. Ecol., 56: 85-97.

Nevalainen, L. \& K. Sarmaja-Korjonen. 2008. Intensity of autumnal gamogenesis in chydorid (Cladocera, Chydoridae) communities in southern Finland, with a focus on Alonella nana (Baird). Aquat. Ecol., 42: 151-163.

Nevalainen, L., T.P. Luoto \& K. Sarmaja-Korjonen. 2008. Late Holocene water-level changes in Lake Iso Lehmälampi, southern Finland, reflected in subfossil cladocerans and chironomids. Studia Quaternaria, 25: 33-42.

Nevalainen, L., K. Sarmaja-Korjonen, T.P. Luoto \& S. Kultti. 2011. Does oxygen regulate sexual reproduction in local populations of the littoral cladocera Alonella nana? Hydrobiologia, 661: 463-468.

Nilssen, J.P. \& S. Sandøy. 1990. Recent lake acidification and cladoceran daymaics: surface sediment and core analyses from lakes in Norway, Scotland and Sweden. Phil. Trans. R. Soc. Lond. B, 327: 299-309.

Nyberg, K., J. Vuorenmaa, J. Tammi, P. Nummi, V.-M. Väänänen, J. Mannio \& M. Rask. 2010. Re-establishment of perch in three lakes recovering from acidification: rapid growth associated with abundant food resources. Bor. Env. Res., 15: 480-490.

Odum, E.P. 1969. The strategy of ecosystem development. Science, 164: 262-279.

Odum, E.P. 1985. Trends expected in stressed ecosystems. BioScience, 35: 419-422.

Odum, E.P., J.F. Finn \& E.H. Franz. 1979. Perturbation theory and the subsidity-stress gradient. BioScience, 29: 349-352.

Pękalski, A. 2000. Model of evolution with sexual and nonsexual reproduction. Eur. Phys. J., 13: 791-796.

Pijanowska, J. \& G. Stolpe. 1996. Summer diapause in Daphnia as a reaction to the presence of fish. J. Plankton Res., 18: 1407-1412.

Ponti, B., R. Piscia, R. Bettinetti \& M. Manca. 2010. Longterm adaptation of Daphnia to toxic environment in Lake Orta: the effects of short-term exposure to copper and acidification. J. Limnol., 69: 217-224.

Rispe, C. \& J.-S. Pierre. 1998. Coexistence between cyclical parthenogens, obligate parthenogens, and intermediates in a fluctuating environment. J. Theor. Biol., 195: 97-110.

Rymer, L. \& J. Neale. 1981. Freeze coring as a method of collecting unconsolidated lake sediments. Aust. J. Ecol., 6: $123-126$ 
Sarmaja-Korjonen, K. 1992. Fine-interval pollen and charcoal analyses as tracers of early clearance periods in S Finland. Acta Bot. Fenn., 146: 1-75.

Sarmaja-Korjonen, K. 2003. Chydorid ephippia as indicators of environmental change- biostratigraphical evidence from two lakes in southern Finland. The Holocene, 13: 691700 .

Sarmaja-Korjonen, K. 2004. Chydorid ephippia as indicators of past environmental changes - a new method. Hydrobiologia, 526: 129-136.

Schindler, D.W., K.H. Mills, D.F. Malley, D.L. Findlay, J.A. Shaerer, I.J. Davies, M.A. Turner, G.A. Lindsey \& D.R. Cruikshank. 1985. Long-term ecosystem stress: the effects of years of experimental acidification on a small lake. Science, 228: 1965-1401.

Shumway, R.S. \& D.D. Stoffer. 2006. Time series analysis and its application. Springer, New York: $575 \mathrm{pp}$.

Soucek, D.J., D.S. Cherry \& C.E. Zipper. 2001. Aluminumdominated acute toxicity to the cladoceran Ceriodaphnia dubia in neutral waters downstream of an acid mine drainage discharge. Can. J. Fish. Aquat. Sci., 58: 2396-2404.

Sparling, D.W. \& T.P. Lowe. 1996. Environmental hazards of aluminum to plants, invertebrates, fish, and wildlife. Rev. Environ. Contam. Toxicol., 145: 1-127.

Stross, R.G. \& J.C. Hill. 1965. Diapause induction in Daphnia requires two stimuli. Science, 150: 1462-1464.

Szeroczyńska, K. \& K. Sarmaja-Korjonen. 2007. Atlas of Subfossil Cladocera from Central and Northern Europe. Friends of the Lower Vistula Society, Świecie: $84 \mathrm{pp}$.

Verta, M., J. Mannio, P. Iivonen, J.-P. Hirvi, O. Järvinen \& S. Piepponen. 1990. Trace metals in Finnish head water lakes - effects of acidification and air borne load. In: Kauppi, P., P. Anttila \& K. Kenttämies (Eds), Acidification in Finland. Springer-Verlag, Berlin: 883-908.

Virkanen, J., A. Korhola, M. Tikkanen \& T. Blom. 1997. Recent environmental changes in a naturally acidic rocky lake in southern Finland, as reflected in its sediment geochemistry and biostratigraphy. J. Paleolimnol., 17: 191-213.

Received: April 2011

Accepted: May 2011 